\title{
PENGARUH MODEL PEMBELAJARAN KOOPERATIF TIPE STUDENT FACILITATOR AND EXPLAINING (SFAE) DAN KOMPETENSI PEDAGOGIK GURU TERHADAP PRESTASI BELAJAR PENGANTAR PARIWISATA SISWA KELAS XI JURUSAN PERHOTELAN DI SMKN 2 SINGARAJA
}

\author{
Siti Nurul Rahmah, I Nyoman Natajaya, I Gusti Ketut Arya Sunu \\ Program Studi Administrasi Pendidikan, Program Pascasarjana \\ Universitas Pendidikan Ganesha \\ Singaraja, Indonesia \\ e-mail: \{nurul.rahmah, nyoman.natajaya, arya.sunu\}@pasca.undiksha.ac.id
}

\begin{abstract}
Abstrak
Penelitian ini bertujuan untuk mengetahui pengaruh model pembelajaran kooperatif tipe student facilitator and explaining (SFAE) dan kompetensi pedagogik guru terhadap prestasi belajar Pengantar Pariwisata.Penelitian ini adalah penelitian eksperimen dengan menggunakan rancangan penelitian semu dengan pola "The Posttest-Only Control Design".Populasi dalam penelitian ini adalah semua siswa kelas XI Jurusan Perhotelan di SMKN 2 Singaraja sebanyak 158 siswa.Sampel diambil dengan teknik random sampling dengan besar sampel 77 orang.Data dikumpulkan dengan tes yaitu tes objektif.Analisis data dilakukan dengan Anakova. Hasil penelitian menunjukkan bahwa: (1) terdapat pengaruh yang signifikan model pembelajaran kooperatif tipe SFAE (Student Facilitator and Explaining) terhadap prestasi belajar dalam mata pelajaran Pengantar Pariwisata. Prestasi belajar siswa yang dibelajarkan dengan menggunakan model pembelajaran kooperatif tipe SFAE lebih tinggi dari pada prestasi belajar siswa yang dibelajarkan dengan menggunakan pembelajaran konvensional. Kualifikasi prestasi belajar yang dibelajarkan dengan menggunakan model pembelajaran kooperatif tipe SFAE berada pada katagori sangat tinggi sedangkan prestasi belajar yang dibelajarkan dengan menggunakan pembelajaran konvensional berada pada katagori tinggi.(2) terdapat pengaruh yang signifikan model pembelajaran kooperatif tipe SFAE terhadap prestasi belajar dalam mata pelajaran Pengantar Pariwisata setelah kovariabel kompetensi pedagogik dikendalikan. (3) terdapat kontribusi yang signifikan kovariabel kompetensi pedagogik guru terhadap prestasi belajar Pengantar Pariwisata. Berdasarkan temuan-temuan di atas dapat disimpulkan bahwa model pembelajaran kooperatif tipe SFAE berpengaruh yang signifikan terhadap prestasi belajar pengantar pariwisata baik sebelum maupun setelah kovariabel kompetensi pedagogik dikendalikan

Kata kunci: SFAE (Student Facilitator and Explaining) kompetensi pedagogik, prestasi belajar
\end{abstract}

\section{Abstract}

This study aims to determine the effect of cooperative learning model of student facilitator and explaining (SFAE) and teacher pedagogic competence on Tourism Introduction learning achievement. This research is experimental research by using quasi research design with "The Posttest-Only Control Design" pattern. The population in this study were the whole of the elevent class division hospitality in SMK N 2 Singaraja were 158 student. The sampel take by random sampling with a large sample of 77 people. Data was collected by test as objektif test. Data analysis was performed with Anakova. The result of the research shows that: (1) there is significant influence of learning achievement in tourism introduction which follow cooperative learning model of student facilitator and explaining (SFAE) type and follow the conventional learning. Student achievement using SFAE type cooperative learning model is higher than the learning achievement using conventional learning. Qualifications of learning achievement by using SFAE type cooperative learning model are in very high category, and the learning achievement using conventional learning is in high category. (2) There is significant influence in learning achievement between learning achievement by using cooperative learning model of SFAE type and conventional learning after covariabel of pedagogic competence is controlled. (3) there is a significant contribution of pedagogic competence to learning achievement in tourism introduction. Based on the above findings, it can be concluded that SFAE type cooperative learning model influences significantly on tourism introduction learning achievement both before and after covariabel of pedagogic competence is controlled.

Keywords: SFAE(Student Facilitator and Explaining) pedagogic competency, learning achievement 


\section{PENDAHULUAN}

Hasil dari kegiataan yang berupa prestasi belajar menjadi ujung dari proses kegiatan pembelajaran, dimana berguna sebagai alat ukur sejauh mana subyek mampu menguasai materi yang telah disampaikan oleh guru. Namun tidak hanya itu, prestasi belajar dapat pula memberikan cerminan keberhasilan seorang guru dalam melaksanakan proses pembelajaran, evaluasi dan pelaporan yang berbentuk prestasi belajar merupakan bentuk suatu pertanggungjawaban atas usaha mengajar yang dilakukan oleh pendidik. Selain itu prestasi juga berguna untuk menyusun tindak lanjut yang dapat dilakukan pendidik, orang tua maupun peserta didik yang bersangkutan. Prestasi belajar juga berguna untuk mengetahui kedudukan peserta didik dalam kelas. Hal ini menjadikan prestasi belajar sebagai salah satu tanda tercapainya tujuan pembelajaran.

Tetapi kenyataan yang ada, rendahnya mutu pendidikan salah satunya disebabkan proses pembelajaran yang belum efektif. Penggunaan model pembelajaran adalah suatu usaha yang dilakukan oleh pendidik agar seorang peserta didik dapat maksimal dalam memahami materi pelajaran, sehingga setelah melakukan pembelajaran peserta didikakan memiliki kompetensi sebagaimana tuntutan dari materi pelajaran yang dipelajari.

Berdasarkan pengamatan tiga (3) tahun terakhir pada mata pelajaran Pengantar Pariwisata kelas XI Jurusan Perhotelan di SMKN 2 Singaraja dapat diketahui bahwa untuk prestasi belajar peserta didik rata-ratanya hanya 68,45 . Hal ini juga didukung daribanyaknya siswa yang harus mengikuti remidial guna mencapai nilai KKM (Kriteria Kelulusan Minimal) yang telah ditentukan yaitu 80(KKM Sekolah) dan ketuntasan belajar dikatakan berhasil apabila terjadi perubahan perilaku kurang lebih $75 \%$.

Pendidik menjelaskan beberapa penyebab yang memungkinkan hal tersebut terjadi diantaranya dikarenakan masih kurang pahamnya peserta didik pada materi yang telah diajarkan serta disebabkan pula kurangnya buku referensi yang diperlukan.

Seperti yang telah diketahui mata pelajaran Pengantar Pariwisata merupakan mata pelajaran peminatan yang berarti bahwa pemilihan mata pelajaran tersebut disesuaikan dengan minat, bakat, maupun kemampuan peserta didik dan dilakukan atas dasar kebutuhan untuk lanjut ke tahap berikutnya. Namun, selain beberapa masalah yang diketahui dari hasil wawancara dengan pendidik, peneliti juga melakukan pengamatan ketika pembelajaran berlangsung,dimana untuk partisipasi dan keaktifan peserta didik saat pembelajaran rendah yang dapat terlihat ketika pendidik mengajukan pertanyaan, hanya beberapa peserta didik yang menjawab pertanyaan dari pendidik. Begitu pula saat pendidik.memberikan kesempatan peserta didik untuk bertanya maka tidak ada peserta didik yang mengajukan pertanyaan berkaitan dengan materi pelajaran Pengantar Pariwisata yang disampaikan pendidik.atau dapat dikatakan peserta didik dalam menerima pelajaran yang bersifat teoritis cenderung pasif.

Partisipasi dan keaktifan peserta didik dalam kegiatan pembelajaran sangat diperlukan, dikarenakan adanya keterlibatan mental maupun pikiran individu menunjukkan adanya minat yang besar yang akan mendorong kemampuan peserta didik dalam mencapai tujuan pembelajaran. Perhatian peserta didiksaat mengikuti pembelajaran rendah. Hal tersebut ditunjukkan pada saat guru memberikan penjelasan, siswa kurang memperhatikan. Hanya ada beberapa siswa yang pemperhatikan penjelasan guru. Sementara siswa yang lain memperhatikan obyeklain seperti mengobrol dengan teman semeja, melamun, maupun meletakkan kepala diatas meja.

Hal lain yang nampak yaitu kurangnya kedisiplinan siswa dalam mengumpulkan tugas yang diberikan oleh guru, dimana tugas dikumpulkan tidak sesuai instruksi yang diberikan. Adanya perhatian dalam suatu kegiatan menunjukkan adanya pemusatan tenaga psikis yang tertuju pada suatu objek, jadi apabila tidak ada perhatian dalam kegiatan belajar dapat dikatakan minat siswa kurang dalam hal tersebut.Berbagai gejala yang menggambarkan rendahnya minat belajar siswa diantaranya yaitu masih kurangnya partisipasi, keaktifan, perhatian, dan juga kedisiplinan siswa dalam kegiatan pembelajaran seperti yang telah digambarkan sebelumnya sangat mempengaruhi kegiatan belajar. 
Selain itu, kekurangaktifan siswa yang terlihat dalam pembelajaran dapat terjadi karena model yang digunakan kurang melibatkan aktivitas siswa secara langsung.Pembelajaran di kelas masih banyak didominasi oleh guru sehingga kurang mampu membangun minat dan sikap siswa siswa yang lebih baik.Dengan kurangnya minat dan sikap siswa tersebut berdampak terhadap prestasi belajar siswa yang secara umum kurang memuaskan.

Hal tersebut terjadi karena kegiatan belajar mengajar dan model pembelajaran yang digunakan oleh guru di sekolah masih berpusat pada guru (teacher centered) yaitu pembelajaran kovensional berupa ceramah. Selain nilai siswa yang rendah akibat pembelajaran yang kurang menarik, di sekolah tersebut pula terkendala oleh sarana dan prasarana pembelajaran.

Adanya kecenderungan proses pembelajaran seperti inilah sehingga siswa sulit menangkap dan memahami materi yang disampaikan oleh guru. Siswa menjadi malas bertanya dan hanya menerima yang disampaikan oleh guru saja. Padahal dalam proses pembelajaran sebaiknya melakukan pembelajaran dua arah, hal tersebut sesuai dengan pengertian pembelajaran: Pembelajaran adalah proses interaksi antar peserta didik, antara peserta didik dengan pendidik dan sumber belajar pada suatu lingkungan belajar (Anonim, 2013: 5) Pembelajaran kovensional merupakan suatu istilah dalam pembelajaran yang lazim diterapkan dalam pembelajaran sehari-hari. Jadi dalam kegiatan pembelajaran siswa hanya mendengarkan bahan pelajaran yang disampaikan oleh guru.

Keadaan yang seperti itu maka salah satu upaya yang dapat dilakukan guru dalam proses pembelajaran adalah dengan menggunakan model pembelajaran lain. Penggunaan model yang tepat maka standar keberhasilan yang ditetapkan dalam suatu kegiatan pembelajaran akan efektif. Untuk mencapai kegiatan tersebut, maka diperlukan suatu model pembelajaran yang mendukung siswa berperan aktif di dalamnya.

Situasi pembelajaran tersebut yang membuat peneliti ingin mencoba mengedepankan pembelajaran yang mempunyai interaksi dua arah, yaitu ada timbal balik antara guru dan siswa, serta suasana belajar yang menyenangkan dan menarik sehingga siswa mampu mengembangkan ide-ide gagasan mereka dan berani untuk mempresentasikan di depan kelas. Untuk mewujudkan hal itu maka pada penelitian kali ini peneliti mencoba pembelajaran dengan menggunakan model pembelajaran kooperatif tipe Student Facilitator and Explaining(SFAE). Menurut Istarani (2011:1) adapun pengertian model pembelajaran sebagai berikut: Seluruh rangkaian penyajian materi ajar yang meliputi segala aspek sebelum, sedang dan sesudah pembelajaran yang dilakukan guru serta segala fasilitas yang terkait yang digunakan secara langsung atau tidak langsung dalam proses belajar mengajar.

Model pembelajaran kooperatif tipeStudent Facilitator and Explaining(SFAE).adalah model pembelajaran yang menempatkan siswa/peserta didik untuk mempresentasikan ide atau pendapat pada siswa lainnya sehingga siswa akan dilatih untuk memiliki kecakapan berbicara dan memberikan ide-ide baru secara individu yang dapat meningkatkan prestasi belajar siswa.

Perbedaan model Student Facilitator and Explaining dengan model konvensional terletak pada cara pertukaran pikiran antar siswa. Dimana dalam model Student Facilitator and Explaining siswa dapat menerangkan dengan bagan atau peta konsep. Model pembelajaran kooperatif tipe Student Facilitator and Explaining (SFAE)pada penelitian ini akan diterapkan pada mata pelajaran Pengantar Pariwisata. Sehingga materi tersebut mampu terwakili dengan menggunakan peta konsep.

Adapun kelebihan dari model pembelajaran kooperatif tipe Student Facilitator and Explaining (SFAE)yang diperoleh saat penelitian yaitu dapat mendorong tumbuh dan berkembangnya potensi berpikir kritis siswa secara optimal; melatih siswa aktif, kreatif dalam menghadapi setiap permasalahan; mendorong tumbuhnya tenggang rasa, mau mendengarkan dan menghargai pendapat orang lain; mendorong tumbuhnya sikap demonstransi; mendorong tumbuhnya keberanian mengutarakan pendapat siswa secara terbuka; dan memperluas wawasan siswa melalui kegiatan saling bertukar informasi, pendapat dan pengalaman antar mereka. 
Selain model pembelajaran hal terpenting dalam peningkatan prestasi belajar siswa adalah kompetensi yang dimiliki oleh guru, Kompetensi yang dimaksud disini adalah kompetensi pedagogik guru.Dalam proses belajar mengajar pendidik memilki peran menentukan kualitas mengajaran yang dilaksanakannya. Yakni memberikan pengetahuan (kongnitif), sikap dan nilai (affektif), dan keterampilan (psikomotorik). Dengan kata lain, tugas dan peran guru yang utama terletak dibidang pengajaran. Pengajaran merupakan alat untuk mencapai tujuan pendidikan. Oleh karena itu seorang guru dituntut untuk dapat mengelola kelas, pengguanaan metode mengajar, strategi mengajar, maupun sikap dan karakteristik guru dalam mengelolah proses belajar mengajar yang efektif, mengembangkan bahan pengajaran dengan baik, dan meningkatkan kemampuan siswa untuk menyimak pelajaran dan menguasai tujuan pendidikan yang harus mereka capai.

Berdasarkan pernyataan di atas maka model pembelajaran kooperatif tipe Student Facilitator and Explaining (SFAE)dapat menjadi model pembelajaran yang efektif, efisien, dan memiliki daya tarik tersendiri jika diterapkan di dalam kelas. Oleh karena itu peneliti tertarik untuk mengambil penelitian yang berjudul "Pengaruh Model Pembelajaran Kooperatif Tipe Student Facilitator And Explaining(SFAE)dan Kompetensi Pedagogik Guru terhadap Prestasi Belajar Pengantar Pariwisata Siswa Kelas XI Jurusan Perhotelan di SMKN 2 Singaraja".

\section{METODE PENELITIAN}

Penelitian ini menggunakan metode eksperimen, dengan menggunakan rancangan penelitian "Posttest Only Control Group Design." Pada kelompok eksperimen pembelajaran dilaksanakan menggunakan model pembelajaran kooperatif tipe Student Facilitator and Explaining (SFAE) sedangkan pada kelompok kontrol, asesmen pembelajaran dilaksanakan dengan pembelajaran konvensional.

Menurut Agung $(2014 ; 69)$ menyatakan populasi adalah keseluruhan objek dalam suatu penelitian. Populasi pada penelitian ini adalah seluruh siswa kelas XI Jurusan Perhotelan di SMKN 2 Singaraja, yang berjumlah 158 orang. Sampel pada penelitian ini dilakukan tanpa adanya pengacakan individu, cara ini dipilih dengan mempertimbangkan sulitnya untuk merubah kelas yang sudah terbentuk. Kelas dipilih sebagaimana yang telah terbentuk tanpa adanya campur tangan dari peneliti.Sebelum dilakukan pemilihan sampel, terlebih dahulu dilakukan uji kesetaraan kelas dengan menggunakan analisis anava satu jalur.

Nilai $F$ hitung sebesar 1,113 dengan signifikansi sebesar 0,346. Hasil tersebut menunjukkan bahwa signifikansi lebih besar dari 0,05, sehingga dapat disimpulkan bahwa tidak ada perbedaan kemampuan siswa atau kemampuan siswa setara.

Penelitian ini meyelidiki pengaruh dua variabel bebas terhadap duavariabel terikat.Variabel independent (bebas) tersebut adalah variabel yang mempengaruhi atau menjadi sebab perubahan variabel terikat. Variabel dependen (terikat) adalah variabel yang dipengaruhi atau yang menjadi akibat karena adanya variabel bebas. Kedua variabel bebas tersebut adalah yakni variabel model pembelajaran kooperatif tipe Student Facilitator and Explaining dan model pembelajaran konvensional. Model pembelajaran kooperatif tipe Student Facilitator and Explainingdiberikan pada kelompok eksperimen dan model pembelajaran konvensional diberikan pada kelompok kontrol.Sedangkan variabel terikat yang diteliti dalam penelitian ini adalah kompetensi pedagogik dan prestasi belajar.Kompetensi pedagogik guru adalah skor yang diperoleh jawaban kuesioner guru.Sedangkan prestasi belajar di dapatkan dari hasil tes pada akhir penelitian.

Penelitian pendahuluan perlu dilakukan untuk pengumpulan data awal tentang efektivitas program bantuan operasional sekolah. Penelitian pendahuluan dilakukan melalui wawancara dengan guru di SMKN 2 Singaraja.dan penanggung jawab program pembekalan, siswa dan para guru dan komite sekolah. Hasil penelitian pada pendahuluan mendapatkan data awal yang berupa masalah-masalah yang dialami dalam metode supervisi yang sudah diterapkan selama ini. 
Data yang dikumpulkan dalam penelitian ini meliputi: 1) kompetensi pedagogik guruguru di SMKN 2 Singaraja, 2) prestasi belajar siswa di SMKN 2 Singaraja, dan 3) respon guru terhadap penerapan model pembelajaran kooperatif tipe Student Facilitator and Explaining.

Pada suatu penelitian ilmiah alat pengumpul data yang digunakan harus memenuhi persyaratan. Kuesioner variabel wawasan tentang kompetensi pedagogik, kualitas pengelolaan pembelajaran, dan respon guru tentang penerapan model pembelajaran kooperatif tipe Student Facilitator and Explaining terhadap guru-guru sebelum digunakan untuk mengumpulkan data, terlebih dahulu diujicobakan untuk mengetahui validitas dan reliabilitasnya adalah mengungkap apa yang hendak diukur. Ada dua persyaratan pokok dari instrumen yang digunakan untuk pengumpulan data penelitian yakni validitas dan reliabilitas (Hamzah, et.al, 2007:63). Validitas berhubungan dengan ketepatan terhadap apa yang mesti diukur oleh instrumen dan seberapa cepat istrumen melakukan pengukurannya, atau dengan kata lain validitas instrumen diukur sehingga betul-betul bias mengukur apa yang seharusnya diukur (Arikunto, 2001:65).

Pendeskripsian data prestasi belajar siswa dan kompetensi pedagogik guru berdasarkan tendensi data, meliputi mean, median, modus, standar deviasi, varians, rentangan, skor maksimum, dan skor minimum. Sebaran data prestasi belajar dan kompetensi pedagogik guru disajikan dalam bentuk tabel dan gambar diagram untuk masing-masing pembelajaran konvensional.

Kualifikasi data prestasi belajar dan kompetensi pedagogik guru, juga menggunakan analisis univariant. Analisis ini didasarkan pada skor rerata ideal (Mi) dan simpangan baku ideal (SDi). Kriteria kualifikasi perubahan data prestasi belajar dan kompetensi pedagogik guru digolongkan menjadi lima. Untuk analisis kovarian diperlukan beberapa persyaratan analisis adalah uji normalitas sebaran data, uji homogenitas varians, dan uji linieritas.

Analisis data yang digunakan adalah Anakova.Untuk menguji hipotesis 1, digunakan analisis varians satu jalur.Untuk menguji hipotesis 2 , digunakan analisis kovarian satu jalur dengan kovariabel kompetensi pedagogic.Untuk menguji hipotesis 3, yaitu mengetahui hubungan kovariabel kompetensi pedagogik guru terhadap prestasi belajarpengantar pariwisata siswa digunakan korelasi product moment.

\section{HASIL PENELITIAN DAN PEMBAHASAN}

1. Pengaruh Model Pembelajaran Kooperatif tipe Student Facilitator and Explaining (SFAE) Terhadap Prestasi Belajar Pengantar Pariwisata

Analisis deskriptif tentang kompetensi pedagogik dengan menggunakan model pembelajaran kooperatif tipe SFAE menunjukkan bahwa rata-rata skor kompetensi pedagogik dengan menggunakan model pembelajaran kooperatif tipe SFAE adalah 181,94 lebih besar dari rata-rata kompetensi pedagogik dengan menggunakan pembelajaran konvensional yaitu sebesar 150,68. Begitupula dengan rata-rata skor prestasi belajar dengan menggunakan model pembelajaran kooperatif tipe SFAE yaitu sebesar 29,97 lebih besar dari rata-rata prestasi belajar dengan menggunakan pembelajaran konvensional yaitu sebesar 25,21. Oleh karena itu dapat disimpulkan bahwa kompetensi pedagogik dengan menggunakan model pembelajaran kooperatif tipe SFAE lebih baik daripada kompetensi pedagogik dengan menggunakan pembelajaran konvensional dan prestasi belajar dengan menggunakan model pembelajaran kooperatif tipe SFAE lebih baik daripada prestasi belajar dengan menggunakan pembelajaran konvensional.

Hasil uji hipotesis pertama telah berhasil menolak hipotesis nol yang menyatakan bahwa tidak terdapat pengaruh yang signifikan antaramodel pembelajaran kooperatif tipe Student Facilitator and Explaining (SFAE) terhadap prestasi belajar pengantar pariwisata siswa kelas XI jurusan perhotelan di SMK Negeri 2 Singaraja dengan skor $F A_{\text {hitung }}=41,274$, dan $p<0,05$. Dari rata-rata skor prestasi belajar dengan menggunakan model pembelajaran kooperatif tipe SFAE $=29,97$ dan rata-rata skor prestasi belajar dengan menggunakan pembelajaran konvensional 25,21. Sehingga secara keseluruhan, prestasi belajar dengan 
menggunakan model pembelajaran kooperatif tipe SFAE lebih tinggi daripada prestasi belajar dengan menggunakan pembelajaran konvensional.Dari hasil uji hipotesis tersebut mengisyaratkan bahwa model pembelajaran kooperatif tipe SFAE lebih unggul dalam meningkatkan prestasi belajar.

Hasil penelitian tersebut sejalan dengan penelitian yang dilakukan Pande (2013) yang berjudul Pengaruh Model Pembelajaran Student Facilitator and Explaining Terhadap Prestasi Belajar Matematika Siswa Kelas V Semester II SD Negeri 2 Gianyar. Pada penelitiannya dinyatakan bahwa perbedaan prestasi belajar matematika antara siswa yang mengikuti proses pembelajaran menggunakan model pembelajaran Student Facilitator and Explaining dengan siswa yang mengikuti proses pembelajaran menggunakan model pembelajaran konvensional, dan prestasi belajar matematika siswa yang mengikuti proses pembelajaran menggunakan model pembelajaran Student Facilitator and Explaining dan rata-rata 14,95, sedangkan siswa yang mengikuti proses pembelajaran menggunakan model pembelajaran konvensional dengan rata-rata 14,70. Hasil penelitian ini menunjukan bahwa model pembelajaran Student Facilitator and Explaining dapat mempengaruhi prestasi belajar matematika.

Model pembelajaran Student Facilitator and Explaining (SFAE)merupakan salahsatu dari tipe model pembelajaran kooperatif. Di dalam kelas kooperatif siswabelajar bersama dalam kelompok-kelompok kecil yang terdiri dari 4-6 orang siswayang sederajat tetapi heterogen, kemampuan, jenis kelamin, suku/ras, dan satusama lain saling membantu. Tujuan dibentuknya kelompok tersebut adalah untukmemberikan kesempatan kepada semua siswa untuk dapat terlibat secara aktifdalam proses berpikir dan kegiatan belajar mengajar.

Model Student Facilitator and Explaining merupakan suatumodel yang memberikan kesempatan kepada siswa atau peserta untuk mempresentasikan ide atau pendapat pada rekan peserta lainnya. Model Student Facilitator and Explaining mempunyai kelebihan yaitu siswa diajak untuk dapatmenjelaskan kepada siswa lain, siswa dapat mengeluarkan ide-ide yang adadipikirannya sehingga dapat lebih memahami materi tersebut.Model pembelajaran Student Facilitator and Explaining adalah modelpembelajaran yang digunakan oleh pendidik dengan maksud meminta pesertadidik untuk berperan menjadi narasumber terhadap temannya di kelas.

Prestasi belajar adalah hasil belajar yang dicapai ketika mengikuti, mengerjakan tugas dan kegiatan pembelajaran di sekolah. Prestasi belajar dinilai dari aspek kognitifnya karena menyangkut kemampuan siswa dalam pengetahuan atau ingatan, pemahaman, aplikasi, analisis, sintesa dan evaluasi. Prestasi belajar dibuktikan dan ditunjukkan melalui nilai atau angka dari hasil evaluasi yang dilakukan oleh guru. Jadi prestasi belajar adalah hasil atau taraf kemampuan yang telah dicapai siswa setelah mengikuti proses belajar mengajar dalam waktu tertentu baik berupa perubahan tingkah laku, keterampilan dan pengetahuan kemudian akan diukur, dinilai yang kemudian diwujudkan dalam angka atau pernyataansebagai pencapaian hasil belajar siswa. Sementarapengertian mengajar pada hakikatnya adalah suatu proses,yaitu proses mengatur, mengorganisasi lingkungan yang ada disekitar anak didik, sehingga dapat menumbuhkan dan mendorong anak didik melakukan proses belajar. Dalam kegiatan belajar, guru berperan sebagai pembimbing, yang mana dalam perannya sebagai pembimbing, guru harus berusaha menghidupkan dan memberikan motivasi, agar terjadi proses interaksi yang kondusif. Dengan demikian cara mengajar guru haruslah efektif dan dimengerti oleh anak didiknya, baik dalam menggunakan model pembelajaran, tehnik ataupun metode dalam mengajar yang akan disampaikan kepada anak didiknya dalam proses belajar mengajardan disesuaikan dengan konsep yang diajarkan berdasarkan kebutuhan siswa dalam proses belajar mengajar.

Mengacu pada hal tersebut diatas, dapat dipahami bahwa dengan menerapkan model pembelajaran yang inovatif, dalam hal ini model pembelajaran kooperatif tipe Student Facilitator and Explaining (SFAE) maka dapat diketahui terdapat pengaruhyang signifikan 
terhadap prestasi belajar siswa dalam mata pelajaran Pengantar Pariwisata.Siswa Kelas XI Jurusan Perhotelan Di SMK Negeri 2 Singaraja.

\section{Pengaruh Model Pembelajaran Kooperatif tipe Student Facilitator and Explaining (SFAE) Terhadap Prestasi Belajar Pengantar Pariwisata}

Kedua,terdapat pengaruh yang signifikan antara model pembelajaran kooperatif tipe Student Facilitator and Explaining (SFAE) terhadap prestasi belajar pengantar pariwisata siswa kelas XI jurusan perhotelan di SMK Negeri 2 Singaraja setelah kovariabel kompetensi pedagogik guru dikendalikan. Hasil uji hipotesis kedua telah berhasil menolak hipotesis nol yang menyatakan tidak terdapat pengaruh yang signifikan antara model pembelajaran kooperatif tipe Student Facilitator and Explaining (SFAE) terhadap prestasi belajar pengantar pariwisata siswa kelas XI jurusan perhotelan di SMK Negeri 2 Singaraja setelah kovariabel kompetensi pedagogik guru dikendalikan. Hal ini tampak dengan melihat harga $F_{\text {hitung }}$ sebesar 27,368 $>F_{\text {tabel }}=4,00$ nilai signifikansi lebih kecil daripada 0,05 yaitu sebesar 0,000. Hal ini berarti hipotesis nol $\left(\mathrm{H}_{0}\right)$ di tolak dan hipotesis $1\left(\mathrm{H}_{1}\right)$ yang menyatakan bahwa "terdapat pengaruh yang signifikan antara model pembelajaran kooperatif tipe Student Facilitator and Explaining (SFAE) terhadap prestasi belajar pengantar pariwisata siswa kelas $\mathrm{XI}$ jurusan perhotelan di SMK Negeri 2 Singaraja setelah kovariabel kompetensi pedagogik guru dikendalikan", diterima.

Hasil ini sekaligus membuktikan bahwa prestasi belajar siswa dengan menggunakan model pembelajaran kooperatif tipe SFAE memang lebih baik daripada prestasi belajar siswa yang mengikuti pembelajaran konvensional sekalipun ditinjau dari kompetensi pedagogiknya.Temuan dalam penelitian ini juga sejalan dengan hasil penelitian yang dilakukan oleh Fitriyani (2016) yang berjudul Pengaruh Model Pembelajaran SFAE (Student Facilitator and Explaining) Terhadap Prestasi Belajar Siswa Pada Kompetensi Dasar Menganalisis Perkembangan Demokrasi dalam Kehidupan Bermasyarakat, Berbangsa dan Bernegara (Studi Pada Kelas XI SMAN 8 Surakarta Tahun Ajaran 2015/2016). Pada penelitiannyadinyatakan bahwa korelasi antara model pembelajaran SFAE terhadap prestasi belajar siswa pada kompetensi dasar menganalisis perkembangan demokrasi dalam kehidupan bermasyarakat, berbangsa dan bernegara sebesar 0,457. Hasil perhitungan uji hipotesis pada rtabel dengan $\mathrm{N}=30$ dan taraf signifikansi $5 \%$ diperoleh rtabel 0,361 . Hasil Analisis menunjukkan bahwa rhitung $(0,457)>$ rtabel $(0,361)$, sehingga dapat diketahui pengaruh model pembelajaran SFAE $(X)$ terhadap prestasi belajar siswa pada kompetensi dasar menganalisis perkembangan demokrasi dalam kehidupan bermasyarakat, berbangsa dan bernegara $(\mathrm{Y})$ sebesar $20 \%$.

Berdasarkan hasil analisis data dan hasil penelitian yang terdahulu, terbukti bahwa terdapat pengaruh interaksi kompetensi pedagogik terhadap prestasi belajar.Prestasi belajar dipengaruhi oleh banyak faktor, baik faktor internal maupun faktor eksternal.Faktor internal merupakan faktor yang berasal dari dalam diri individu, salah satunya adalah kompetensi pedagogik.

Kompetensi pedagogik merupakan kompetensi khas yang membedakan guru dengan profesi lainnya. Kompetensi ini juga akan menentukan keberhasilan proses pembelajaran. Ujung akhir dari kompetensi pedagogik adalah kemampuan dalam mengelola pembelajaran yang mendidik, namun untuk mencapai kemampuan itu seorang pendidik harus memahami karakteristik peserta didik, karakteristik materi yang diajarkan dan juga filosofi pendidikan yang dilaksanakan.

Secara pedagogis, kompetensi guru dalam mengelola pembelajaran perlu diperhatikan karena tak jarang ketidakberhasilan pendidikan disebabkan oleh kompetensi guru. Pendidikan yang baik itu adalah yang memberdayakan bukan penindasan.Jadi pembelajaran yang baik itu bukan guru yang aktif, dan siswa pasif. Akan tetapi pembelajaran itu harus bersifat dialogis dan bermakna, siswa harus aktif dan guru harus memiliki kompetensi yang memadai.Kompetensi pedagogik adalah kemampuan guru dalam mengelola pembelajaran. Dalam hal ini kedudukan guru sebagai menajerial 
pembelajaran.Kemampuan mengelola pembelajaran, secara operasional mencakup tiga fungsi manajerial yaituperencanaan, pelaksanaan, danpengendalian.

Peningkatan kompetensi pedagogik akan menghindarkan dari kegiatan pembelajaran yang monoton yang membuat siswa kurang minat dan kurang berkonsentrasi dalam belajar. Apabila kompetensi pedagogik yang dimiliki oleh guru itu baik maka ia akan lebih mudah dalam mengelola pembelajaran, menyampaikan materi maupun dalam meningkatkan motivasi siswa

Dengan demikian bahwa kompetensi pedagogik guru memiliki berpengaruh pada motivasi belajar siswa yang akan berlanjut pada prestasi belajar siswa, dan juga dapat mempengaruhi perkembangan kepribadian peserta didik. Untukituperluadanyapeningkatankompetensipedagogik inidisampingpeningkatankompetensi profesional, sosial maupun personal

Model Student Facilitator and Explainingmemiliki kelebihan yaitu, dapat mendorong tumbuh dan berkembangya potensi berpikir kritis siswa secara optimal, melatih siswa aktif, kreatif dalam menghadapi setiap permasalahan, mendorong tumbuhnya tenggang rasa, mau mendengarkan dan menghargai pendapat orang lain, mendorong tumbuhnya sikap demonstrasi, melatih siswa untuk meningkatkan kemampuan saling bertukar pendapat secara obyektif, rasional guna menemukan suatu kebenaran dalam kerjasama anggota kelompok.

Berdasarkan pemaparan diatas dapat diketahui terdapat pengaruh yang signifikan model pembelajaran kooperatif tipe Student Facilitator and Explainingterhadap prestasi belajar pengantar pariwisata siswa kelas XI jurusan perhotelan di SMK Negeri 2 Singaraja setelah kovariabel kompetensi pedagogik dikendalikan.

\section{Kontribusi Kovariabel Kompetensi Pedagogik Guru Terhadap Prestasi Belajar Pengantar Pariwisata Siswa}

Ketiga, terdapat kontribusi kompetensi pedagogik terhadap prestasi belajar.Kompetensi pedagogik dalam penelitian ini memberikan kontribusi positif terhadap prestasi belajar, walaupun tetap dipengaruhi oleh faktor-faktor yang lainnya.Kontribusi kovaribel kompetensi pedagogik terhadap prestasi belajar, ditunjukan dengan melihat harga $r_{\text {hitung }}$ sebesar 0,594 yang lebih besar dari pada $r$ tabel $(0,215)$. Keselarasan $r^{2}$ sebesar 0,352 yang berarti $35,2 \%$ perubahan pada prestasi belajar dapat diterangkan oleh kompetensi pedagogik. Dengan demikian, kompetensi pedagogik memang berkontribusi positif terhadap prestasi belajar.

Peningkatan kompetensi pedagogik akan menghindarkan dari kegiatan pembelajaran yang monoton yang membuat siswa kurang minat dan kurang berkonsentrasi dalam belajar. Apabila kompetensi pedagogik yang dimiliki oleh guru itu baik maka ia akan lebih mudah dalam mengelola pembelajaran, menyampaikan materi maupun dalam meningkatkan motivasi siswa

Dengan demikian bahwa kompetensi pedagogik guru memiliki berpengaruh pada motivasi belajar siswa yang akan berlanjut pada prestasi belajar siswa, dan juga dapat mempengaruhi perkembangan kepribadian peserta didik. Untuk itu perlu adanya peningkatan kompetensi pedagogik ini disamping peningkatan kompetensi profesional, sosial maupun personal

Berdasarkan aspek-aspek yang terdapat pada kompetensi pedagogik guru, maka dapat diduga terdapat kontribusi yang signifikan kovariabel kompetensi pedagogik guru terhadap prestasi belajar pengantar pariwisata siswa.

\section{PENUTUP}

Berdasarkan hasil pengujian hipotesis dan pembahasan, dapat ditarik simpulan sebagai berikut.

Pertama, terdapat pengaruh yang signifikan model pembelajaran kooperatif tipe SFAE terhadap prestasi belajar dalam mata pelajaran Pengantar Pariwisata siswa kelas XI Jurusan Perhotelan di SMKN 2 Singaraja Prestasi belajar siswa dengan menggunakan model 
pembelajaran kooperatif tipe SFAE lebih tinggi dari pada prestasi belajar menggunakan pembelajaran konvensional. Kualifikasi prestasi belajar dengan menggunakan model pembelajaran kooperatif tipe SFAE berada pada katagori sangat tinggi, dan prestasi belajar dengan menggunakan pembelajaran konvensional berada pada katagori tinggi.

Kedua, Terdapat pengaruh yang signifikan model pembelajaran kooperatif tipe SFAE (Student Facilitator and Explaining)terhadap prestasi belajar dalam mata pelajaran Pengantar Pariwisata siswa kelas XI Jurusan Perhotelan di SMKN 2 Singaraja setelah kovariabel kompetensi pedagogik guru dikendalikan.

Ketiga terdapat kontribusi yang signifikan kovariabel kompetensi pedagogik terhadap prestasi belajar. Berdasarkan temuan-temuan di atas dapat disimpulkan bahwa model pembelajaran kooperatif tipe SFAE(Student Facilitator and Explaining)berpengaruh terhadap prestasi belajar setelah kovariabel kompetensi pedagogik dikendalikan.

Berdasarkan kesimpulan dan implikasi penelitian yang telah dipaparkan di atas, maka dapat disarankan beberapa hal yaitu sebagai berikut.

Kepada pendidikdiharapkan lebih menambah wawasan atau pengetahuan tentang pembelajaran inovatif, dan mampu mengembangkan inovasi pembelajaran dalam menerapkan metode serta modelpembelajaran SFAE (Student Facilitator and Explaining) dalam pembelajaran Pengantar Pariwisata sehingga proses pembelajaran menjadi lebih bermakna serta dapat meningkatkan prestasi belajar siswa.

Melihat keterbatasan waktu dan pokok bahasan yang digunakan dalam penelitian ini, maka disarankan penelitian lain agar melaksanakan penelitian sejenis dengan pemilihan variabel yang berbeda dan waktu yang lebih lama untuk mendapatkan gambaran yang lebih meyakinkan mengenai pengaruh model pembelajaran kooperatif tipe SFAE terhadap prestasi belajar ditinjau dari kompetensi pedagogik guru. Dalam penelitian ini variabelnya juga dapat dikembangkan sehingga nantinya dapat memperoleh hasil yang lebih baik.

Kepada peserta didik diharapkan menjadi aktif dan lebih bersemangat dalam mengikuti proses pembelajaran serta mampu mengembangkan pengetahuannya sendiri untuk mencapai hasil belajar yang optimal

Kepada sekolah diharapkan dengan hasil penelitian ini dapat memberikan informasi untuk menciptakan kondisi pembelajaran yang menarik dan menyenangkan serta mampu mendorong para guru untuk mencoba menerapkan model-model pembelajaran yang baru untuk meningkatkan kualitas proses pembelajaran di sekolah

\section{DAFTAR RUJUKAN}

Agung, AA.G.2014. MetodologiPenelitian Pendidikan. Malang: Aditya Media Publishing.

Arikunto, S. 2001. Prosedur Penelitian, Suatu Pendeketan Praktek. Jakarta:Bina Aksara

Hamzah, B. U. 2007.Teori Motivasi dan Pengukurannya. Jakarta: Bumi Aksana.

Istarani.2011. 58 Model Pembelajaran Inovatif (referensi Guru Dalam Menentukan model Pembelajaran). Medan: Media Persada

Mulyasa, E. 2004. Implementasi Kurikulum Berbasis Kompetensi. Bandung: Cipta Cekas Grafika.

Pande, Km. 2013. yang berjudul Pengaruh Model Pembelajaran Student Facilitator and Explaining Terhadap Prestasi Belajar Matematika Siswa Kelas V Semester II SD Negeri 2 Gianyar. E-Jurnal Mimbar PGSD Volume 1 Nomor 1.

Fitriyani, D. 2016. Pengaruh Model Pembelajaran SFAE (Student Facilitator and Explaining) Terhadap Prestasi Belajar Siswa Pada Kompetensi Dasar Menganalisis Perkembangan Demokrasi dalam Kehidupan Bermasyarakat, Berbangsa dan 
JAPI, Vol. 10 No. 1, Bulan April Tahun 2019

ISSN: 2613-9561

Bernegara (Studi Pada Kelas XI SMAN 8 Surakarta Tahun Ajaran 2015/2016). Tesis. Universitas Sebelas Maret. 